\title{
How mothers keep their babies warm
}

\author{
C J Bacon, S A Bell, E E Clulow, A B Beattie
}

\begin{abstract}
Details of room temperature, clothing, and bedding used by night and by day and in winter and in summer were recorded for 649 babies aged 8 to 26 weeks. Room temperature at night was significantly related to outside temperature and duration of heating. Total insulation was significantly related to outside temperature and to minimum room temperature, but there was wide variation in insulation at the same room temperature. High levels of insulation for a given room temperature were found particularly at night and in winter, and were associated with the use of thick or doubled duvets and with swaddling. At least half the babies threw off some or all of their bedding at night, and at least a quarter sweated. Younger mothers and mothers in the lower social groups put more bedclothes over their babies, and the latter also kept their rooms warmer. Many mothers kept their babies warmer during infections.
\end{abstract}

There has recently been interest in the thermal environment of sleeping babies, arising mainly from suggestions that some cases of sudden infant death syndrome (SIDS) $)^{1-4}$ and haemorrhagic shock and encephalopathy syndrome $(\text { HSES })^{5}$ may be linked with overheating. A difficulty in evaluating this hypothesis has been the lack of control data. There have been four published surveys, from Exeter, ${ }^{6}$ Nottingham, ${ }^{7}$ Leicester, ${ }^{8}$ and Dunedin (New Zealand), ${ }^{9}$ of how mothers keep their babies warm.

We present the findings of a population survey of the thermal environment of 649 sleeping babies by day and night in summer and in winter.

Subjects and methods

A total of 978 mothers living in the Newcastle health district were randomly selected by systematic sampling from birth notifications over a period of three years (1985-7) and were approached for interview. Of these $329(33.6 \%)$ declined to participate or were not available. The social class distribution (by father's occupation) of the 649 mothers who accepted was skewed towards the upper end of the scale compared with the $10 \%$ sample of births for Newcastle reported for 1986 by the Office of Population Censuses and Surveys (OPCS) (table 1). ${ }^{10}$ There were few families from ethnic minorities. One person using a standard questionnaire interviewed these 649 mothers, once only, when their babies were about 8 weeks $(n=204), 16$
Table 1 Class distribution of study group according to father's occupation compared with the OPCS $10 \%$ sample $(1986)^{10}$

\begin{tabular}{lcc}
\hline & $\begin{array}{l}\text { No (\%) of } \\
\text { study group } \\
(n=649)\end{array}$ & $\begin{array}{l}\text { OPCS } \\
10 \% \text { sample }\end{array}$ \\
\hline I & $69(10 \cdot 6)$ & \\
II & $115(17 \cdot 7)$ & $14 \cdot 5$ \\
III Non-manual & $94(14 \cdot 5)$ & $11 \cdot 3$ \\
III Manual & $214(33 \cdot 0)$ & $32 \cdot 4$ \\
IV & $69(10 \cdot 6)$ & $14 \cdot 3$ \\
V & $76(11 \cdot 7)$ & $10 \cdot 8$ \\
Unclassified & $12(1 \cdot 8)$ & $9 \cdot 5$ \\
\hline
\end{tabular}

weeks $(n=238)$, or 26 weeks old $(n=207)$. The interviewer recorded full details of clothing and bedding used for the baby's sleep the previous night and for sleep on the day of the visit, inspecting all items to check their type and material. She also recorded the social background of the family, the gestation and birth weight of the baby, the type and duration of heating, the ventilation of the room, whether the baby sweated while sleeping, and what adjustments the mother made if the baby had an infection.

The ambient temperature of the baby's sleeping place was measured, for day by a recording at the time of the visit, for night by a maximumminimum thermometer left near the cot and collected next morning (temperature recordings were not available for three babies). Outside temperatures for the same times were obtained from the Meteorological Office. The study continued through all months of the year except August. The data were analysed separately for the 326 mothers who were interviewed in summer and the 323 who were interviewed in winter, summer being defined as the period of British summer time.

ANALYSIS OF INSULATION

The total insulation for each baby was estimated by summing the individual contributions of each item of clothing and bedding. Tog values of materials similar to those found in the survey were measured by the method described in British Standard $4745 .^{11}$ (The tog is a unit of thermal resistance, one tog being 10 times the temperature difference in ${ }^{\circ} \mathrm{C}$ between the surfaces of a material when the heat flow through it is 1 watt $/ \mathrm{m}^{2}$.) The insulation contributed by each item was calculated from the tog value of its material and the proportion of the body, excluding the head, that it covered (table 2). For duvets, which vary widely in tog rating, the value for the individual brand was ascertained in accordance with British Standard 5335..$^{12}$ If 
Table 2 Amount of insulation contributed by each item of clothing and bedding, and proportion of surface area covered (excluding the head)

\begin{tabular}{lll}
\hline & $\begin{array}{l}\text { Thermal } \\
\text { resistance } \\
\text { of fabric } \\
\text { (tog) }\end{array}$ & $\begin{array}{l}\text { Proportion } \\
\text { of surface } \\
\text { area covered } \\
\text { (excluding head) }\end{array}$ \\
\hline Clothing: & & \\
Sleeping suit without hood & 4.0 & 1.00 \\
Babygro with feet & 1.0 & 0.91 \\
Quilted jacket & 2.0 & 0.5 \\
Cardigan & 2.0 & 0.45 \\
Tee-shirt & 0.8 & 0.45 \\
Vest & 0.2 & 0.38 \\
Tights & 0.8 & 0.45 \\
Dungarees & 0.4 & 0.56 \\
Socks & 0.2 & 0.09 \\
Mittens & 2.0 & 0.10 \\
Nappies: & 3.5 & 0.19 \\
Terry nappy as worn, dry & 0.4 & 0.19 \\
Terry nappy as worn, wet & 4.0 & 0.19 \\
Disposable nappy, dry & 0.4 & 0.19 \\
Disposable nappy, wet & 0.4 & 1.0 \\
Bedding: & 0.2 & 1.0 \\
Sheet & 1.5 & 1.0 \\
Blanket & $4-13.5$ \\
Duvet &
\end{tabular}

items were doubled, twice their tog value was taken.

\section{STATISTICAL METHODS}

The mean (SEM) temperature and insulation for different groups were compared. Significance was usually assessed by Student's $t$ test, paired where appropriate. Two way analysis of
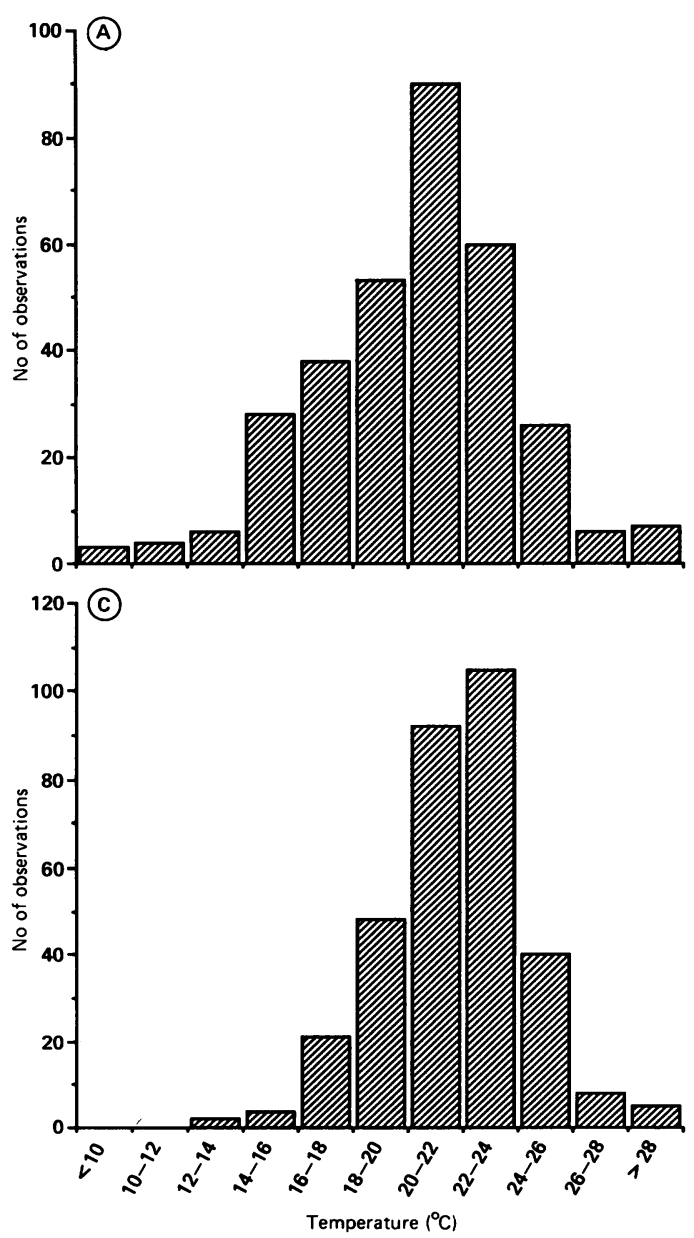

variance was done where appropriate. The association between temperature and insulation was examined by comparison of the mean insulations for a series of temperature ranges; regression analysis was not done because the association was not linear or sequential.

\section{Results}

AMBIENT TEMPERATURE AND HEATING

The distributions of ambient temperature near the baby's sleeping place at night in winter and summer are shown in fig 1 . Modal values for minimum and maximum temperatures were $15^{\circ} \mathrm{C}$ and $20^{\circ} \mathrm{C}$ in winter, and $19^{\circ} \mathrm{C}$ and $23^{\circ} \mathrm{C}$ in summer.

During winter $76(23.5 \%)$ babies' rooms were heated all night and $217(66.9 \%)$ for part of it, and in summer $20(6 \cdot 1 \%)$ and $245(75 \cdot 4 \%)$, respectively. Figure 2 shows the association between outside temperature and minimum room temperature on winter nights, according to the presence and duration of heating. Regardless of heating, room temperature varied significantly compared with outside temperature $(\mathrm{p}<0.01$, two way analysis of variance), though the difference between them was greater on colder nights. For a given outside temperature rooms heated all night were on average $4 \cdot 2^{\circ} \mathrm{C}$ warmer, and rooms heated for part of the
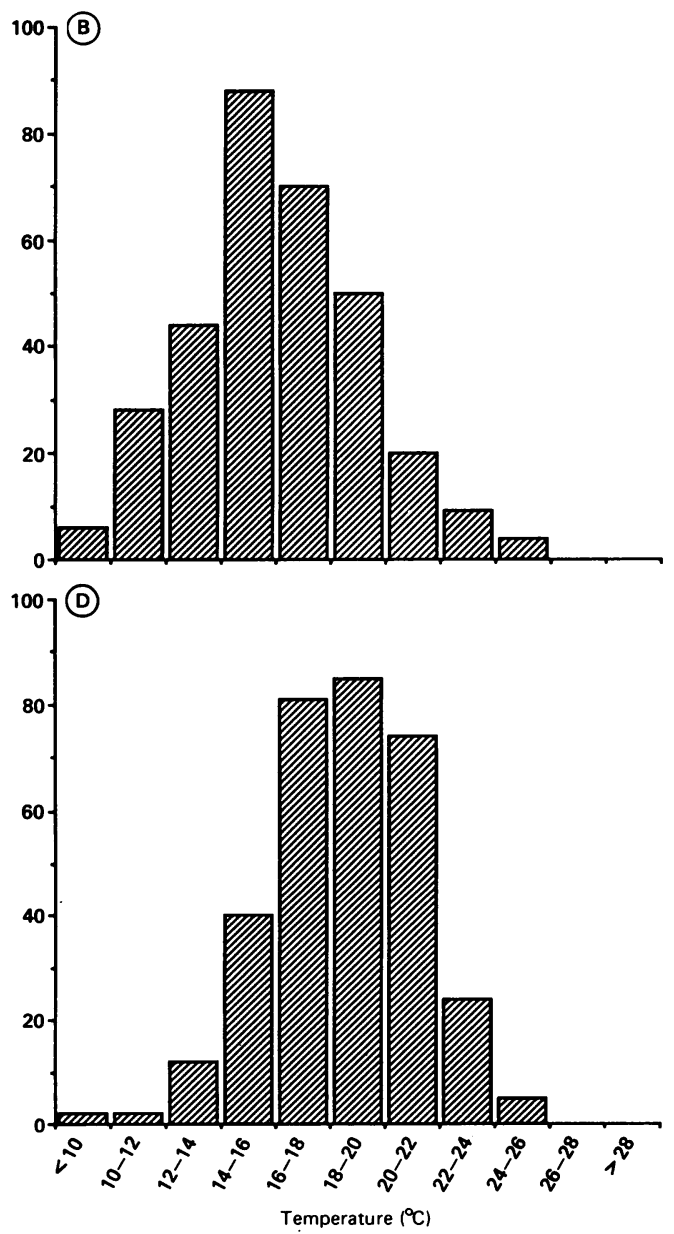

Figure 1 Maximum and minimum ambient temperatures $\left({ }^{\circ} \mathrm{C}\right)$ for sleeping babies at night during winter and summer. Summer is defined as the period of British summer time, but does not include August. (A) maximum room temperature (winter); $(B)$ minimum room temperature (winter); $(C)$ maximum room temperature (summer); and $(D)$ minimum room temperature (summer) 


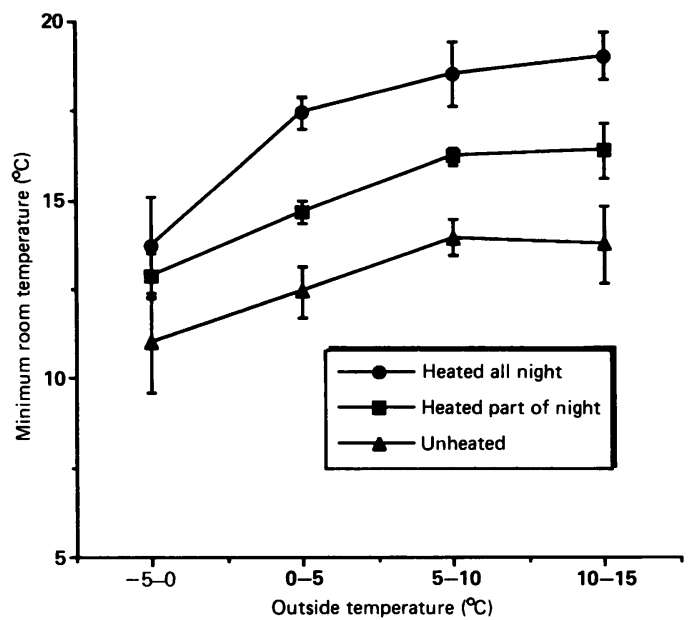

Figure 2 The association between outside temperature on winter nights and minimum temperature in heated and unheated rooms. Mean (SEM) room temperatures were calculated for each $5^{\circ} \mathrm{C}$ band of outside temperature.

night were $2 \cdot 2^{\circ} \mathrm{C}$ warmer, than rooms with no heating at all.

Of the total, 190 babies (29.3\%) slept in their own bedrooms at night, $442(68 \cdot 1 \%)$ shared their parents' bedrooms, and $15(2 \cdot 3 \%)$ slept in living rooms. The temperature in separate and shared bedrooms were similar, but living rooms were usually warmer than bedrooms, the mean maximum temperature being significantly higher $\left(23.93(1.21)^{\circ} \mathrm{C}\right.$ compared with 20.45 $\left.(0 \cdot 13)^{\circ} \mathrm{C}, \mathrm{p}<0 \cdot 01\right)$.

Only 83 mothers $(12 \cdot 8 \%)$ left windows open in their babies' rooms at night, being more likely to do so if the rooms were warmer; 200 babies' rooms $(30.9 \%)$ were totally unventilated at night with windows and doors closed. On winter nights 70 mothers $(21 \cdot 7 \%)$ and on summer nights $23(7 \cdot 1 \%)$ heated the cot before putting the baby down to sleep, for example with an electric blanket or a hot water bottle.

\section{INSULATION}

The means and ranges for total insulation from clothing and bedding put on by day and night in summer and winter are shown in table 3 . The contribution made by clothing was proportionally greater by day when babies were often put down to sleep wearing most of their clothes but with less bedding. Figure 3 shows the association of total insulation on winter nights to outside temperature and to maximum and minimum room temperature. Significantly less total insulation was applied when outside temperatures and when minimum room temperatures were higher (both $p<0.01$, two way analysis of variance). Within this overall relationship, however, there were wide variations between individuals subjects in the amount of insulation applied at the same ambient temperature. The variance was greater in colder weather. The extreme example of variation was provided by two mothers who put on 3.2 tog and 42.0 tog, respectively, for the same minimum room temperature. There was no significant association between total insulation and maximum room temperature at night; indeed, mean insulation was comparatively high for the babies with the warmest rooms.

The extent to which mothers allowed for room heating when deciding how much to insulate their babies varied (table 4). Babies who slept in living rooms tended to be covered a little more than those who slept in bedrooms $(14.4(1.36)$ compared with $13.50(0.2)$ tog).

Figure 4 shows how, for a given room temperature, mothers put on more insulation on

Table 3 Mean (SEM) and range of tog values contributed by clothing and bedding according to season and time

\begin{tabular}{|c|c|c|c|c|}
\hline & \multicolumn{2}{|c|}{ Summer $(n=326)$} & \multicolumn{2}{|c|}{ Winter $(n=323)$} \\
\hline & Day & Night & Day & Night \\
\hline $\begin{array}{l}\text { Total insulation of clothing and bedding (tog): } \\
\text { Mean (SEM) } \\
\text { Range } \\
\text { Mean (SEM) contribution of clothing (tog) }\end{array}$ & $\begin{array}{l}8 \cdot 71(0.29) \\
2.4-22 \cdot 8 \\
4.35(0.07)\end{array}$ & $\begin{array}{c}11.98(0.25) \\
3.2-28 \cdot 2 \\
3.58(0.02)\end{array}$ & $\begin{array}{l}10 \cdot 31(0 \cdot 25) \\
2 \cdot 2-31 \cdot 4 \\
4 \cdot 86(0 \cdot 06)\end{array}$ & $\begin{array}{c}15 \cdot 1(0 \cdot 29) \\
3 \cdot 2-42 \cdot 0 \\
4.56(0.03)\end{array}$ \\
\hline
\end{tabular}
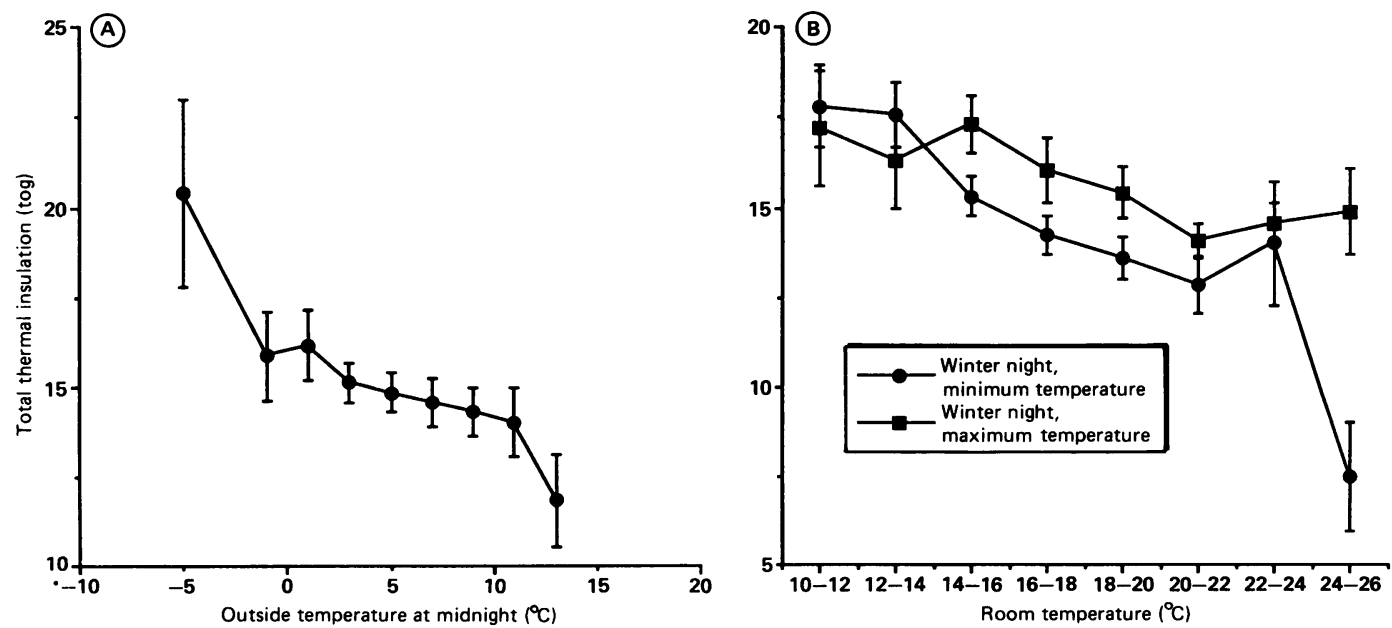

Figure 3 The association between total thermal insulation of sleeping babies on winter nights and $(A)$ outside temperature at midnight; $(B)$ maximum and minimum room temperatures. Mean $(S E M)$ values for insulation were calculated for each $2^{\circ}$ temperature band. 
Table 4 Insulation and outside temperature in heated and unheated rooms on winter nights. Figures are expressed as mean (SEM) tog value

\begin{tabular}{|c|c|c|c|}
\hline $\begin{array}{l}\text { Outside } \\
\text { temperature } \\
\left({ }^{\circ} \mathrm{C}\right)\end{array}$ & $\begin{array}{l}\text { Room not } \\
\text { heated }\end{array}$ & $\begin{array}{l}\text { Room heated } \\
\text { part of night }\end{array}$ & $\begin{array}{l}\text { Room heated } \\
\text { all night }\end{array}$ \\
\hline $0-5$ & $\begin{array}{l}18.09 \\
(n=7)\end{array}$ & $\begin{array}{l}15 \cdot 89(0.56) \\
(n=107)\end{array}$ & $\begin{array}{l}14 \cdot 44(0.66)^{* *} \\
(\mathrm{n}=39)\end{array}$ \\
\hline $5-10$ & & & $\begin{array}{l}13 \cdot 39(1 \cdot 1) \\
(n=19)\end{array}$ \\
\hline $10-15$ & $\begin{array}{l}15 \cdot 05 \\
(n=4)\end{array}$ & $\begin{array}{l}15 \cdot 16(1 \cdot 27) \\
(n=10)\end{array}$ & $\begin{array}{l}11.05(0.92)^{* *} \\
(\mathrm{n}=8)\end{array}$ \\
\hline
\end{tabular}

* and ${ }^{* *}=\mathrm{p}<0.01$.

In 28 other cases the outside temperature was not within the range $0-15^{\circ} \mathrm{C}$.

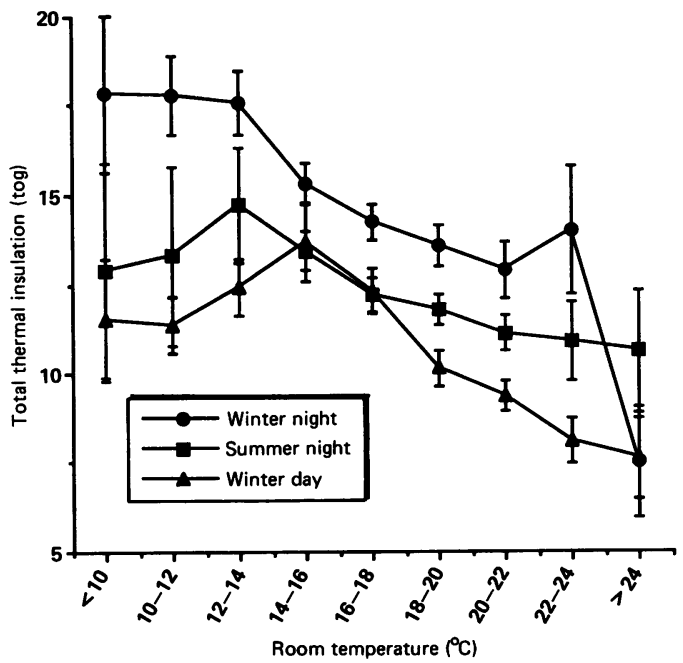

Figure 4 The association between total thermal insulation and room temperature on winter nights, summer nights, and winter days. Mean (SEM) values for insulation were calculated for each $2^{\circ} \mathrm{C}$ temperature band.

winter nights than they did either for summer nights or for sleeps during the day.

Table 2 shows that when duvets were used they contributed much the largest single component of total insulation. In winter 237 (73.5\%) mothers used them by night and 114 $(35.4 \%)$ by day; in summer the numbers were $214(65 \cdot 8 \%)$ and $94(28 \cdot 7 \%)$, respectively. At night total insulation was significantly higher among those with duvets than those without (summer $12.85(0.28)$ compared with $10 \cdot 14$ $(0.43)$ tog, $\mathrm{p}<0.01$; winter $15.45(0.34)$ compared with $14.21(0.56)$ tog, $p<0.05)$ although minimum room temperatures were similar in both groups. The values for total insulation were highest when mothers put on more than one duvet or folded the duvet to give several thicknesses.

\section{ARRANGEMENT OF BEDDING}

Of the total, 384 mothers $(59 \cdot 2 \%)$ reported that their babies usually threw off some or all (79, $12 \cdot 2 \%$ ) of their bedding at night. Babies were more likely to throw off bedding if they were highly insulated in relation to the ambient temperature, with the exception of those with extremely high insulation. They were less likely to do so if they were swaddled or tucked in tightly. There was no age difference in tendency to throw off bedding. One hundred and twenty six mothers $(19 \cdot 4 \%)$ swaddled their babies at night; swaddled babies tended to have higher insulation initially as well as being less likely to throw off bedding. Of the rest, 205 mothers $(31 \cdot 6 \%)$ tucked their babies in tightly, and $15(2 \cdot 3 \%)$ usually took the babies into their own beds for most of the night.

EFFECT OF BABIES' GESTATION, AGE, AND BIRTH WEIGHT

Mothers made no special allowance in their covering or heating of the 37 babies who had been born prematurely (gestation $<37$ weeks). When the three age groups (roughly 8, 16, and 26 weeks) were compared, younger babies tended to have warmer rooms but less insulation on both winter and summer nights (fig 5). Babies with lower birth weights also tended to have warmer rooms but less insulation-for example, the 43 babies with birth weights $<2500 \mathrm{~g}$ had a mean (SEM) minimum room temperature of $17.72(0.4)^{\circ} \mathrm{C}$ and mean insulation of 12.72 $(0.68)$ tog compared with $16.65(0.44)^{\circ} \mathrm{C}$ and $14.22(0.65)$ tog for the 52 who weighed $>4000$ $g$ at birth $(\mathrm{p}<0.05$ in each case).

\section{SWEATING}

Of the total, 183 mothers $(28 \cdot 2 \%)$ said that their babies usually sweated when asleep at night, 27 of them (4.2\%) sweating profusely; and by day the figures were $149(23.0 \%)$ and $12(1.8 \%)$, respectively. There was no differences in the incidence of sweating among babies in different age groups; the same babies tended to sweat by night as by day. At night, babies sleeping in rooms with above average minimum temperatures were significantly more likely to sweat $(\mathrm{p}<0.001)$, but those sleeping under more than average total insulation were not.

\section{ADJUSTMENTS FOR ILLNESS}

When asked what adjustment if any they would make in their baby's covering or heating at night in the event of a febrile illness, 289 $(44.5 \%)$ mothers said they would make no change, $122(18.8 \%)$ said they would keep the baby warmer, and $237(36.5 \%)$ said they would keep the baby cooler.

Of the mothers who would keep the baby warmer, $104(85 \cdot 2 \%)$ said that they would put on more coverings and $27(22 \cdot 1 \%)$ said that they would increase the heating. Of the mothers who said that they would keep the baby cooler, 193

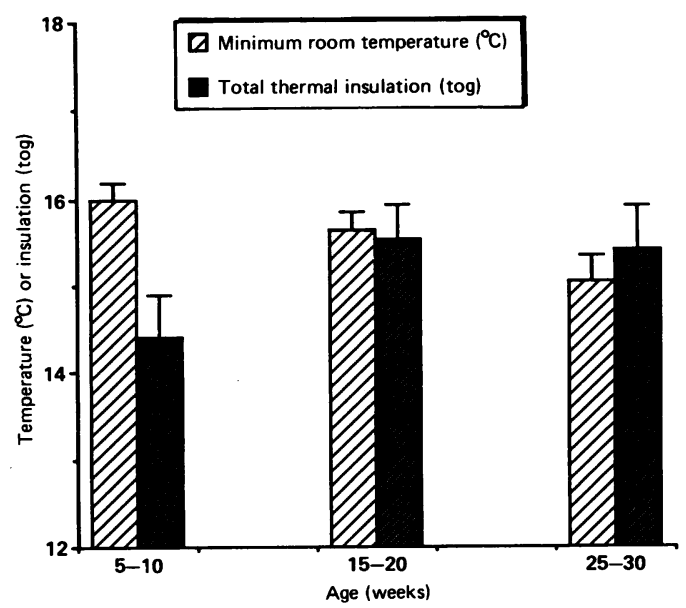

Figure 5 Minimum room temperature and total thermal insulation for babies aged 5-10, 15-20, and 25-30 weeks. 


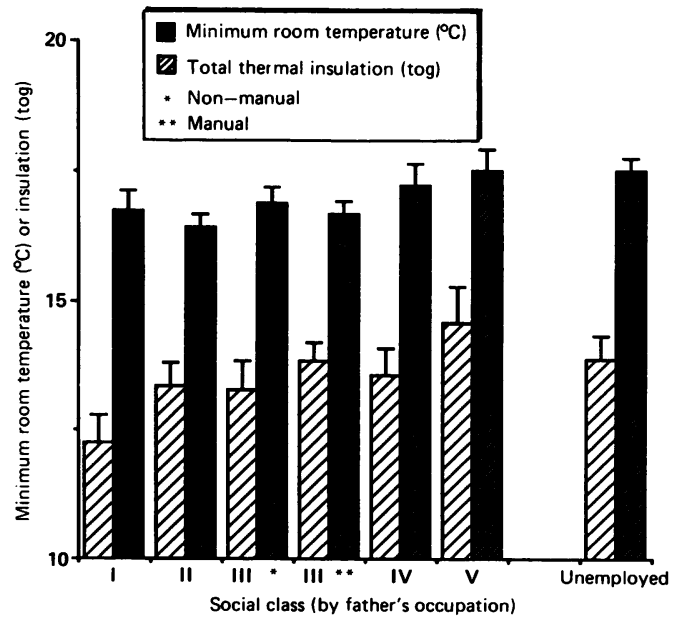

Figure 6 Minimum room temperature and total thermal insulation for babies in families of different social classes subdivided according to father's occupation. When he was unemployed the family was classified both by the last occupation, and as unemployed.

$(81 \cdot 4 \%)$ said that they would put on less covering, $36(15 \cdot 2 \%)$ said that they would decrease the heating, and $63(26.6 \%)$ said that they would give the baby antipyretic medication.

ASSOCIATIONS WITH MATERNAL AGE, PARITY, AND EDUCATION

Mothers in all age groups kept their babies' rooms at about the same temperature. Younger mothers put on significantly more bedding than older mothers; the mean total insulation used by the 39 mothers under 20 years old was $15 \cdot 1(1 \cdot 0)$ tog, compared with $12 \cdot 1(0 \cdot 6)$ tog used by the 53 mothers over 35 years $(p<0 \cdot 01)$. Younger mothers were also more likely to keep their babies warmer when ill. There were no differences in room temperature or insulation used by mothers of different parity, but experienced mothers were more likely to keep their babies cooler when they were ill. The way mothers kept their babies warm was also related to duration of education: those who had left school at the age of $16(n=377)$ used significantly more insulation $(\mathrm{p}<0.05)$ and slightly higher room temperatures than those whose education had continued after the age of $19(n=121)$.

ASSOCIATION WITH OCCUPATIONAL GROUP

The variation in thermal environment at night with occupational group is shown in fig 6 .
Families in the lower groups tended both to keep their babies' rooms warmer at night and to put on more covering, as did families in which the father was unemployed. The differences in insulation between group I and groups II, III, and IV, and between group V and groups I, II, and III (non-manual) were significant $(p<0.05)$. About the same proportion of families in each group had some form of heating in the baby's bedroom, or kept it on all night, or had a window open. Duvets were used to a similar extent in all groups, but many more mothers in the manual groups swaddled their babies. There were no differences among the groups in adjustments that were made for illness, or in the practice of having the baby in the parents' bed.

\section{Discussion}

We think that this is the most comprehensive study of babies' thermal environment yet published. Despite the high non-response rate and consequent skewed distribution of social classes, we have no reason to suppose that our sample was not representative with regard to the practices being studied, and the numbers were sufficient to allow analysis of each social group separately.

Table 5 shows how our figures for ambient temperatures compare with those reported from elsewhere. Mean room temperatures on winter nights in Newcastle, despite its cooler climate, were higher than those found in Leicester or Dunedin, which suggests that mothers in Newcastle used more heating. The differences in mean room temperatures in Newcastle between day and night and between summer and winter were not large, probably because heating damped down fluctuations with outside temperature. Paradoxically the highest room temperature $\left(30^{\circ} \mathrm{C}\right)$ was recorded on a winter night and the lowest $\left(4^{\circ} \mathrm{C}\right)$ by day.

As yet there is no standard method for assessing the insulating effect of babies' clothing and bedding. The method we have used does no more than quantify clothing and bedding on the trunk and limbs and does not attempt to calculate the effective physiological insulation of the whole body. Even in this limited aim we have had to disregard a number of factors including insulation from pillow, underbedding, and mattress; the reduction in insulating properties of items that have been much used and washed, or

Table 5 Reported ambient temperatures for sleeping babies

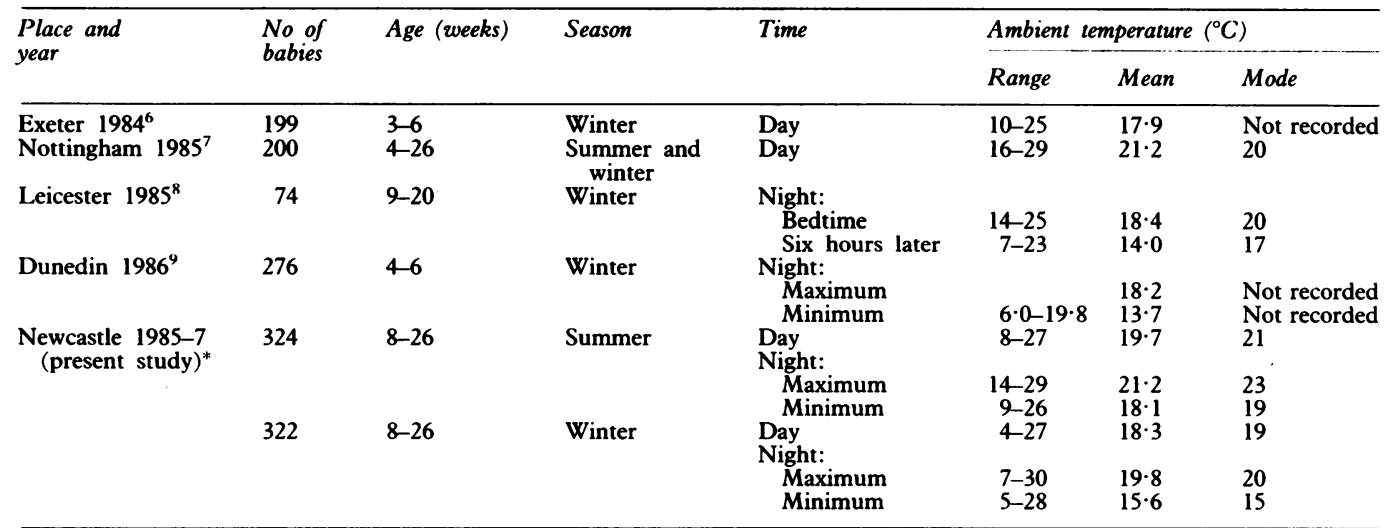

${ }^{*}$ Temperature recordings not available for three babies. 
have been wetted by urine or by sweat; and the effect of the compression of individual layers of bedding. Calculation of the effective physiological insulation of the whole body is complex and needs to take into account various additional factors such as differential heat loss from different parts of the body, especially the uncovered head; the effect of posture; heat loss through curved surfaces; variations in the effectiveness of sweating with materials of varying permeability; and the insulation provided by the boundary layer of air.

The only other study to use the same method of quantification as ours was that done in Leicester which dealt with winter nights only: the mean value for insulation reported was $14 \cdot 7$ tog, which was similar to our value of $15 \cdot 1$ tog. ${ }^{8}$

The influence of social background on the way babies are kept warm differs between England and New Zealand. In Newcastle, as in Exeter $^{6}$ and Leicester (MP Wailoo, personal communication), families in the lower occupational groups kept their babies warmer, with hotter rooms and more bedding, whereas in Dunedin they kept them cooler, with colder rooms and less bedding. 9

Because little is known about thermoregulation in this age group, ideal combinations of ambient temperature and insulation are not established, and there is a lack of informed advice for mothers. Our findings suggest that in consequence there is much inconsistency and sometimes illogicality in how mothers keep their babies warm. For a given room temperature they tend to put on more bedding by night than by day, and more in winter than in summer, which suggests that they are influenced more by their traditions and expectations for the time and the season than by objective assessment of ambient temperature. Often they do not make adequate allowance for room heating. At outside temperatures between $5^{\circ} \mathrm{C}$ and $10^{\circ} \mathrm{C}$, for example, although rooms heated all night were on average $4.2^{\circ} \mathrm{C}$ warmer than unheated rooms, babies in the former had a mean of only 1.2 tog less covering than those in the latter. Similarly, babies who slept in the living room were insulated a little more than babies who slept in bedrooms, although living rooms were generally much warmer. Many mothers did not seem to appreciate that some makes of duvet confer a high degree of insulation, and that duvets are intended as a substitute for and not as an addition to other bedding. It is likely that the widespread introduction of both central heating and of duvets has resulted in sleeping babies being kept much warmer today than in previous generations. The high degree of insulation found at the highest maximum room temperature (fig 3) suggests that there may be a subgroup of mothers who are particularly concerned about keeping their babies warm. Many babies throw off their bedding, and it is possible that they do so because they feel too hot, in which case swaddling or tucking in tightly may deprive them of a beneficial manoeuvre.

It may at first seem surprising that younger and smaller babies, whose greater surface: mass ratio makes them more vulnerable to heat loss, were given less insulation than older and larger babies. This was compensated for by a higher ambient temperature, however, so that the balance of their thermal environment was more like the one that they had experienced in the hospital nursery.

Thirty years ago attention was drawn to the dangers of hypothermia in babies, and mothers were rightly advised to avoid letting their babies get cold. ${ }^{13}$ The lesson seems to have been well learnt, and the OPCS now records few deaths in infancy from this cause. ${ }^{14}$ Has the pendulum now swung too far the other way so that babies are less at risk from cold than from excessive efforts to avoid it?

The babies in our study who were kept warmest did not seem any the worse for it except that some of them sweated, which suggests they may have been under thermal stress. The possibility remains, however, that a high level of insulation that is tolerable in normal circumstances may be dangerous if some other factor intervenes. For example, the baby may rapidly develop a fever, or may slip beneath the coverings so that the main channel for losing surplus heat, through the uncovered head, is lost. ${ }^{15}$ It may be relevant that some of the factors we found to be associated with higher levels of heating and insulation (younger mothers, lower social group, winter season, night) are also associated with SIDS. ${ }^{16}$ Our data offer some support for the hypothesis of 'paradoxical overheating'-babies may be more at risk of hyperthermia when it is cold.

It is vital that these issues are clarified, because if overheating is indeed a contributory factor to some cases of death or damaging illness it would be entirely preventable by soundly based advice to mothers.

This survey was funded by the Foundation for the Study of Infant Deaths. We thank Dr EN Hey and Professor A AynsleyGreen for their advice and support, and the mothers who answered our questionnaire.

1 Stanton AN, Scott DJ, Downham MAPS. Is overheating a factor in some unexpected infant deaths? Lancet 1980;i: factor in

2 Stanton AN. Overheating and cot death. Lancet 1984;ii: 1199-201.

3 Nelson EAS, Taylor BJ, Weatherall IC. Sleeping position and infant bedding may predispose to hyperthermia and the sudden infant death syndrome. Lancet 1989;i:199-201.

4 Fleming PJ, Gilbert R, Azaz Y, et al. The interaction between bedding and sleeping position in sudden infant death syndrome: a population-based controlled study. $B M \mathcal{F}$ 1990;301:85-9.

5 Bacon C, Scott D, Jones P. Heastroke in well-wrapped infants. Lancet 1979;i:422-5.

6 Eiser C, Town C, Tripp J. Dress and care of infants in health and illness. Arch Dis Child 1985;60:465-70.

7 Nicoll A, Davies L. How warm are babies kept at home? Health Visitor 1986;59:113-4.

8 Wailoo MP, Petersen SA, Whittaker H, Goodenough P. The thermal environment in which 3-4 month old infants sleep thermal environment in which 3-4 mois Child 1989;64:600-4.

9 Nelson EAS, Taylor BJ. Infant clothing, bedding and room heating in an area of high postneonatal mortality. Paediatric heating in an area of high postneonatal mortality
and Perinatal Epidemiology 1989;3:146-56.

and Perinatal Epidemiology 1989;3:146-56.
10 Office of Population Censuses and Surveys. Classification of occupations. London: HMSO, 1980.

$11 \mathrm{BS} 4745$. Method for the determination of thermal resistance of textile materials. London: British Standards Institute, 1986. 12 BS 5335 . Specification for continental quilts. London: British Standards Institute, 1984.

13 Bower BD, Jones LF, Weeks MM. Cold injury in the newborn. BMF 1960;i:303-9.

14 Office of Population Censuses and Surveys. Mortality statistics: cause. 1976-85. London: HMSO, 1987.

15 Anderson ES, Wailoo MP, Petersen SA. Use of thermographic imaging to study babies sleeping at home. Arch Dis Child 1990;65:1266-7.

16 Golding J, Limerick S, Macfarlane A. Sudden infant death: patterns, puzzles and problems. Shepton Mallet: Open Books, 1985. 